\title{
Uncoupling of bacteria and phytoplankton during a spring diatom bloom in the mouth of the Yellow Sea
}

\author{
Byung Cheol Cho ${ }^{1}$, Joong-Ki Choi ${ }^{2}$, Chang-Soo Chung ${ }^{3}$, Gi Hoon Hong ${ }^{3}$ \\ ${ }^{1}$ Department of Oceanography, Seoul National University, Shin-lim Dong, Kwan-ak Gu, Seoul 151-742, Republic of Korea \\ ${ }^{2}$ Department of Oceanography, Inha University, Young-hyeon Dong, Inchon 402-751, Republic of Korea \\ ${ }^{3}$ Korea Ocean Research \& Development Institute, Ansan, PO Box 29, Kyunggi Do 425-600, Republic of Korea
}

\begin{abstract}
Bacterial abundance, production, and environmental parameters were investigated to study the distribution of bacterial variables and interrelationships between bacteria and phytoplankton along a transect from the southwestern tip of the Korean Peninsula to the axis of the Yellow Sea in April 1991 The study area showed a tidally induced turbidity maximum in the middle region of the transect. The turbidity maximum had lower phytoplankton abundance, primary production, and bacterial production than the adjacent waters. Diatom blooms were observed in the inner bay and in waters outside of the turbidity maximum. Bacterial abundance and production showed relatively large variations along the transect from 3 to $32 \times 10^{8} \mathrm{l}^{-1}$ and from undetectable to $11.9 \mu \mathrm{g} \mathrm{Cl}^{-1} \mathrm{~d}^{-1}$, respectively. Bacterial and phytoplankton variables did not correlate significantly $(\mathrm{p}>0.12)$. Further, depth-integrated bacterial production over the euphotic zone comprised less than $4 \%$ of primary production, suggesting that bacteria and phytoplankton were not closely coupled during the study period. The uncoupling seemed to be unrelated to phytoplankton community structure. Strong tidal mixing, which would mix the organic matter produced in the euphotic zone into the deeper water column, possibly coupled with mass sinking of phytoplankton to the bottom seemed to cause low substrates level and unbalanced growth for bacteria in the euphotic zone and thereby the observed uncoupling of bacteria from phytoplankton. Further, strong tidal mixing seemed to facilitate the bacterial use of sinking carbon in the aphotic zone.
\end{abstract}

KEY WORDS: Uncoupling B Bacteria $\cdot$ Phytoplankton $\cdot$ Yellow Sea $\cdot$ Diatom bloom

\section{INTRODUCTION}

Bacteria are a significant component in microbial food webs and biogeochemical cycles in marine ecosystems (Azam et al. 1983, Sherr \& Sherr 1988, Azam \& Smith 1991, Ducklow \& Carlson 1992). Bacterial abundance correlates positively with phytoplankton biomass (Bird \& Kalff 1984, Ducklow \& Carlson 1992), and bacterial production with phytoplankton production (Fuhrman \& Azam 1982, Cole et al. 1988, Billen et al. 1990) for large scales of space and time. However, these close relationships have not been often reported for small scales of space and time (Pomeroy \& Deibel 1986, Andersen 1988). Major causes for the uncoupled relationships are thought to be low water temperature (Pomeroy \& Deibel 1986), low substrate
(Pomeroy et al. 1991), or food web structure (Andersen 1988).

Recently, hydrodynamic conditions have been proposed to determine the energy flow and material cycle in the sea (Legendre \& Fevre 1989). In stratified water a 'microbial loop' type of food web appeared, while a shorter 'classical' type of food web appeared to dominate along the deep mixed layer (Kiorboe et al. 1990). Different food chains developed as a result of differences in tidal mixing in the English Channel (Holligan et al. 1984). In our study area (along a transect from the southwestern tip of the Korean Peninsula to the axis of the Yellow Sea) tidal current is strong. Due to the dissipation of the tidal energy (tidal range of 3 to $5 \mathrm{~m}$ ), a high concentration of suspended particulate matter is maintained in the shallow region throughout the year. 
The width of the tidally induced turbidity zone is about $50 \mathrm{~km}$ in the mouth of the Yellow Sea (Hong 1991). Thus, various hydrodynamic environments are expected to occur (i.e. turbidity front, stratified and mixed zones). In this study, we attempted to determine (1) whether and how bacterial abundance and production varied in the various hydrodynamic environments along the transect, (2) whether relationships between bacteria and phytoplankton for biomass and production varied depending on hydrodynamic conditions along the transect, and (3) whether variations of the relationships between bacteria and phytoplankton are related to phytoplankton community structure in the various hydrodynamic environments. Our results showed that bacterial abundance did not correlate with chl a content, and bacterial production was $<4 \%$ of primary production in the euphotic zone during a spring bloom in the mouth of the Yellow Sea where mixing was dominant. The work reported here describes a possible role of strong tidal mixing in causing uncoupling of bacteria from phytoplankton.

\section{MATERIALS AND METHODS}

Sampling area and sample collection. A transect from the southwestern tip of the Korean Peninsula to the axis of the Yellow Sea was occupied between April 8 and 18, 1991 (Fig. 1), where a tidally induced turbid zone is known to exist (Hong 1991). Seawater was collected with a Niskin bottle (10 l) from 4 to 6 depths in the water column.

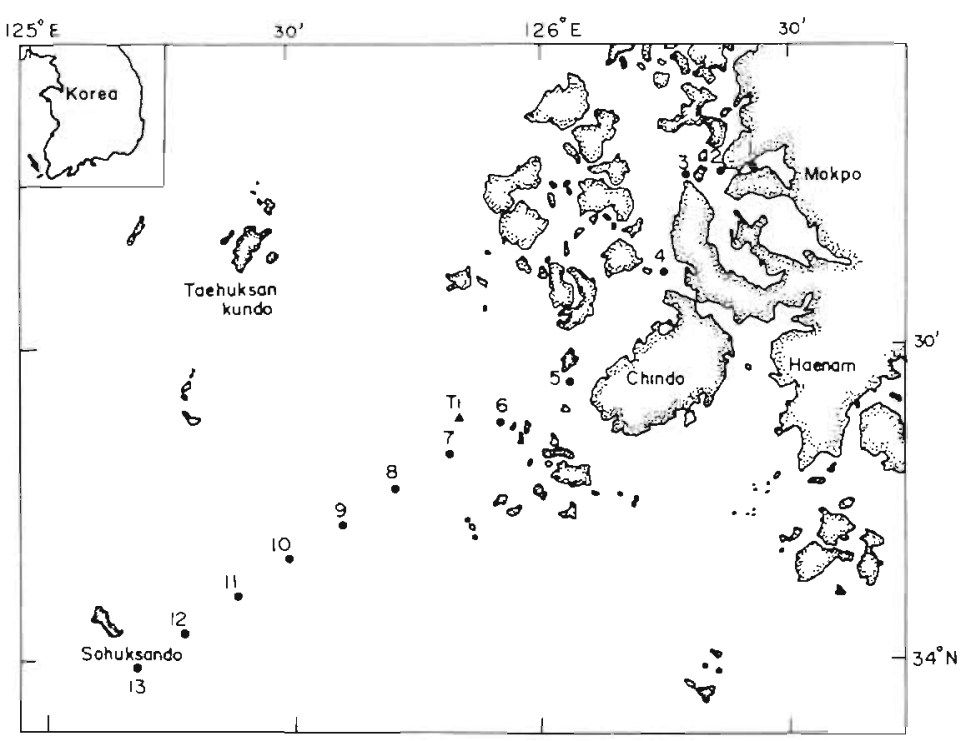

Fig. 1 Sampling stations along a transect from the southwestern tip of the Korean Peninsula to the axis of the Yellow Sea. April 1991. $\mathrm{T}_{1}$ denotes the location of a moored sediment trap
Bacterial variables. Samples for bacterial abundance were fixed with $3 \%$ of $0.22 \mu \mathrm{m}$ filtered, buffered formalin. Bacterial abundance was measured by epifluorescence microscopy after staining bacteria with acridine orange (Hobbie et al. 1977). Bacterial production was measured basically by the method of Fuhrman \& Azam (1982). Briefly, $\left[{ }^{3} \mathrm{H}\right]$ thymidine (Amersham Inc, specific activity $=25 \mathrm{Ci} \mathrm{mmol}^{-1}$ ) was added to $5 \mathrm{ml}$ seawater to give a final concentration of $10 \mathrm{nM}$. The treated samples were incubated in the dark at in situ temperature for $1 \mathrm{~h}$. After incubation, thymidine incorporation was stopped by adding $\mathrm{NaOH}$ and putting samples on ice. The radiolabelled DNA was extracted according to Robarts et al. (1986). Within $3 \mathrm{~h}$, trichloroacetic acid (TCA) was added to the samples, which were then filtered through $0.22 \mu \mathrm{m}$ Millipore filters. The filters were then washed with phenol:chloroform (50\% wt/vol) solution and $80 \%$ ethanol (vol/vol). This procedure was more convenient for use in the field than extraction with hot-TCA. The incorporated radioactivity was converted to the number of cells produced using a conversion factor of $1.1 \times$ $10^{18}$ cells per mole of thymidine incorporated into DNA (Riemann et al. 1987). To estimate bacterial biomass and production, $20 \mathrm{fg} \mathrm{C}$ cell $^{-1}$ (Lee \& Fuhrman 1987) was used. Bacterial doubling time was calculated by dividing bacterial biomass with bacterial production rate.

Phytoplankton parameters. Primary production was measured by the ${ }^{14} \mathrm{C}$-bicarbonate method (Parsons et al. 1984): Water samples, collected by Niskin bottles at 6 different depths $(100,50,25,13,5,0 \%$ of incident light), were treated with ${ }^{14} \mathrm{C}$-bicarbonate (2 $\mu \mathrm{Ci}$, Amersham, Inc.) and incubated at in situ temperature on deck at the corresponding light intensities, achieved using black nylon screen, for $2 \mathrm{~h}$ under natural illumination. Incubations were terminated by filtration of samples on Whatman GF/F glass fiber filters. Since picoplankton comprises a minor fraction $(<5 \%)$ of primary production in the coastal zone of the Yellow Sea in April (Shim et al. 1993), GF/F filters were used to expedite filtration. Filters were kept frozen in a dry ice box until radioassaying by liquid scintillation counting. Instagel (Packard Co.) was used as scintillation cocktail. Chlorophyll a (chl a) was measured according to Parsons et al. (1984). Samples for the quantitative study of phytoplankton were fixed with Lugol's solution. Identification of phytoplankton was done after Hüstedt (1927-66), Cupp (1943), and Abe (1967).

Environmental parameters. Water temperature was measured by placing a calibrated 
thermometer into a Niskin bottle, immediately after samples for measurements of bacterial and phytoplankton parameters were withdrawn. Salinity was determined using an inductive salinometer. Suspended particulate matter (SPM) in dry weight was measured by filtering known volumes of seawater on a combusted $\left(550^{\circ} \mathrm{C} ; 3 \mathrm{~h}\right) \mathrm{GF} / \mathrm{F}$ filter and drying the filter in an oven $\left(105^{\circ} \mathrm{C} ; 2 \mathrm{~h}\right)$. Sinking fluxes of carbon and nitrogen were determined by mooring a time-series sediment trap (Parflux Mark 7G-13, McLane, Inc.), which was deployed at $30 \mathrm{~m}$ depth at a station located between Stns 6 and 7 (Hong 1991). Regression analyses were performed using the 'Systat'.

\section{RESULTS}

\section{Hydrographic observations}

The mouth of the Yellow Sea was characterized by the presence of relatively cold water (ca $2^{\circ} \mathrm{C}$ lower compared to surrounding waters) located between Stns 6 and 9 (Fig. 2A). Between Stns 6 and 13 seawater temperature increased with depth. However, throughout the study area topto-bottom (up to $110 \mathrm{~m}$ depth) and inshore-to-offshore $(150 \mathrm{~km})$ differences in water temperature were $<4^{\circ} \mathrm{C}$. In most stations the temperature difference within the top $30 \mathrm{~m}$ layer was $<1^{\circ} \mathrm{C}$. The salinity structure in the region was also characterized by low salinity between Stns 6 and 10, showing a similar pattern to temperature (Fig. 2B). Thus, temperature and salinity data indicated that a lens with less saline and colder surface water was floating (Fig. 2C) on the more saline and warmer bottom water. The hydrographic environments could be divided into 4 groups on the basis of temperature and salinity (Fig. 2C): (1) coastal waters (Strns 1 to 3), (2) strongly mixed zone (Stns 4 to 6), (3) a surface lens (Stns 6 to 12), and (4) subsurface water mass with higher salinity and seawater temperature. Fronts were expected along the transect to be located between Stns 2 and 4, Stns 5 and 7 , and Stns 8 and 13. Within the lens, weak stratifications (at Stns 7 and 9 to 11) and a mixed zone (at Stn 8) were found.

\section{Suspended particulate matter (SPM)}

The dominant feature of the SPM distribution was a remarkable increase (2- to 7 -fold) with depth, except at Stn 5 where almost uniform concentrations of SPM were found in the water column (14.6 to $21.3 \mathrm{mg} \mathrm{l}^{-1}$, Fig. 3). The highest concentration of SPM was found at Stn 6 at $30 \mathrm{~m}$ depth $\left(56.8 \mathrm{mg} \mathrm{l}^{-1}\right)$. The high SPM zone (>30 $\mathrm{mg} \mathrm{l}^{-1}$ ) was located close to the bottom between Stns 6 and 9 . At the surface, the turbidity maximum was found at Stn 5, which was located in the strongly mixed zone (Fig. 2C). Another noteworthy observation was that SPM concentrations at the surface were always substantial $\left(>2.5 \mathrm{mg} \mathrm{l}^{-1}\right.$ ) throughout the transect, even at $150 \mathrm{~km}$ offshore $\left(4.1 \mathrm{mg} \mathrm{l}^{-1}\right)$. Consequently, the euphotic depth determined by Secchi
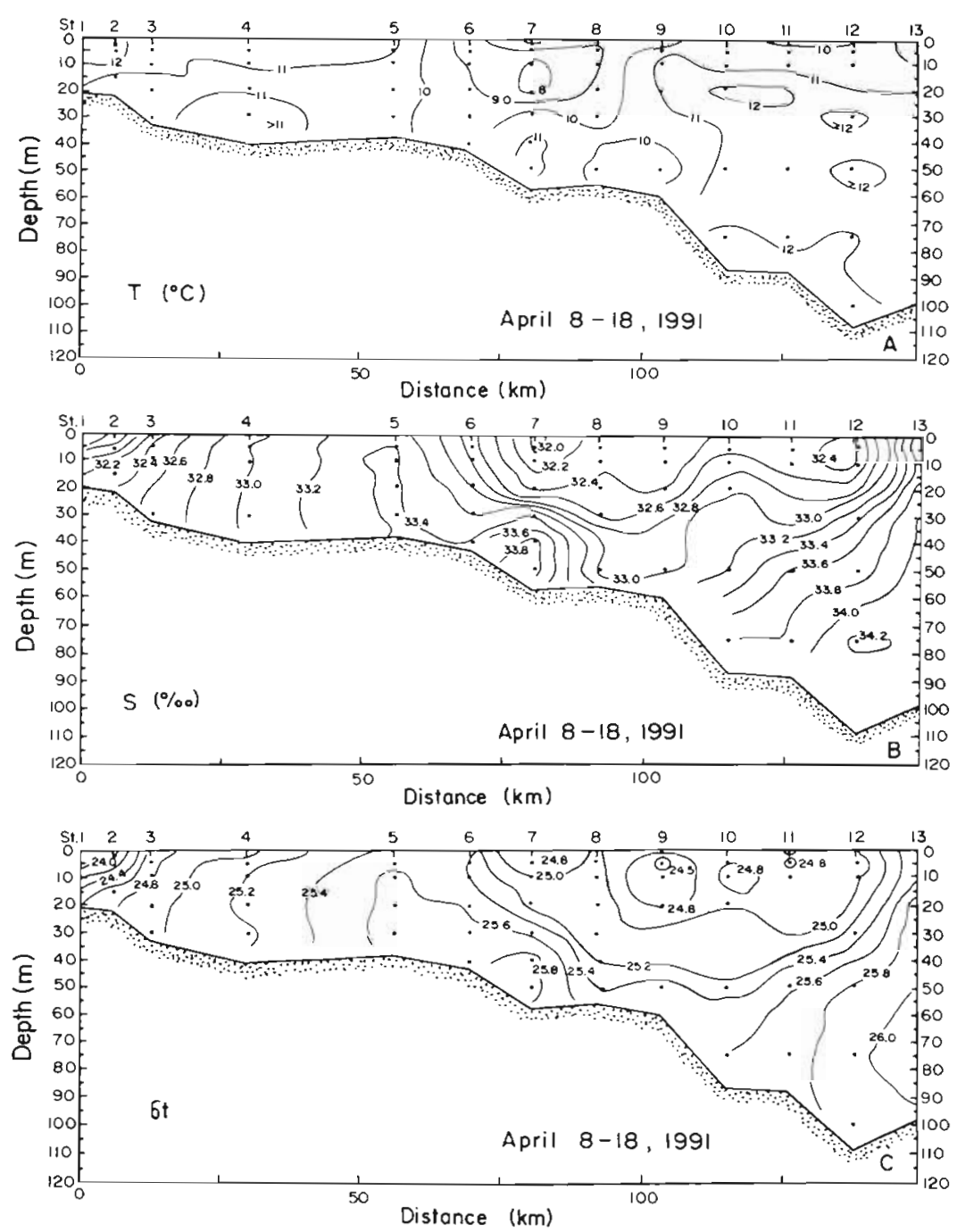

Fig. 2. Isopleth diagrams of (A) seawater temperature, (B) salinity, and (C) density. (•) Depth at which sample was taken 


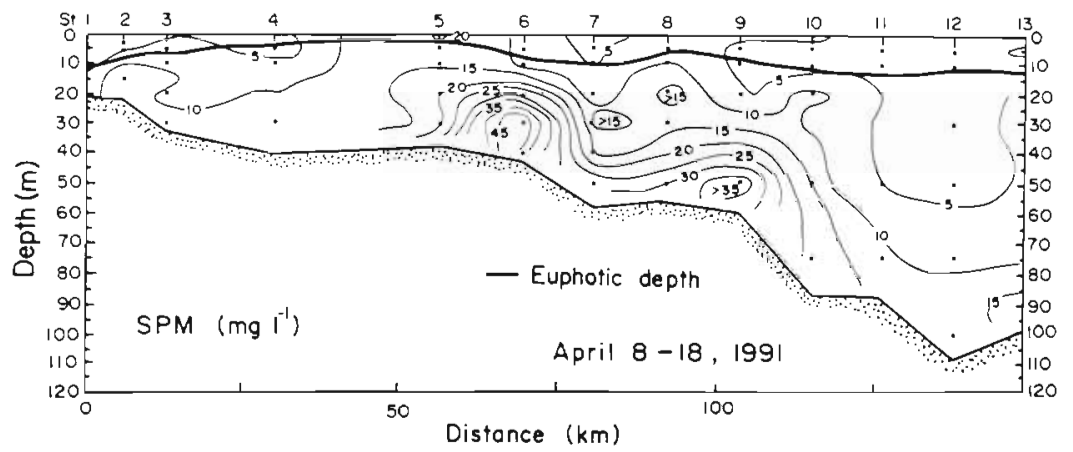

Fig. 3. Isopleth diagram of suspended particulate matter (SPM). (•) Depth at which sample was taken

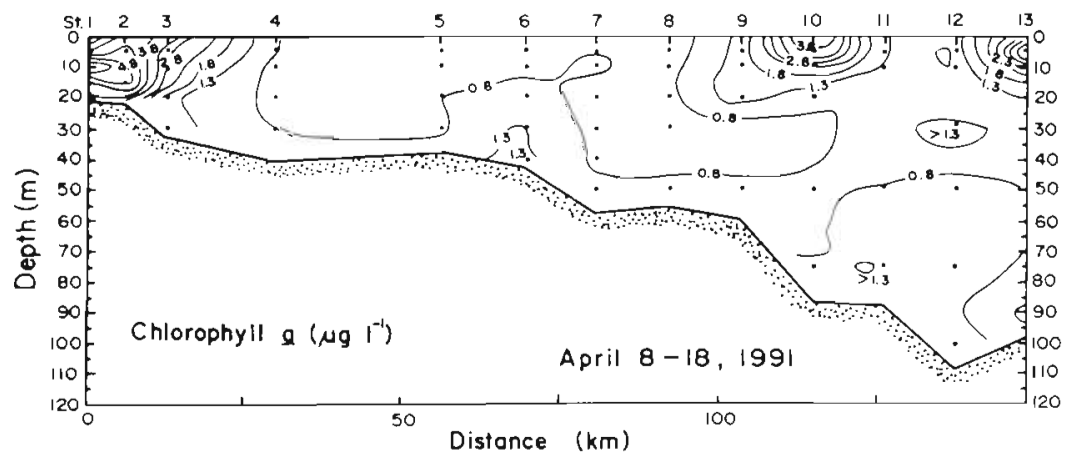

Fig. 4. Isopleth diagram of chlorophyll a. (•) Depth at which sample was taken depth was shallow throughout the study area (Fig. 3). The shallowest euphotic depth $(2.7 \mathrm{~m})$ was found at Stn 5, where a surface turbidity maximum existed.

\section{Chlorophyll a}

Concentrations of chl a ranged from 0.8 to $6.0 \mu \mathrm{g} \mathrm{l}^{-1}$, with the highest value at the coastal Stn 1 at $10 \mathrm{~m}\left(6.0 \mu \mathrm{g} \mathrm{l}^{-1}\right.$, Fig. 4). At most stations maximum concentrations of chl a were found at the bottom of the euphotic zone. However, at some stations (Stns 6,8 and 11) chl a concentration increased with depth. At Stns 3 and 10 the chl a maximum was found at the surface, a typical characteristic of fronts and consistent with hydrographic features (Fig. 2C).

\section{Phytoplankton community structure}

At stations near fronts with phytoplankton blooms (Stns 2, 3, and 10), phytoplankton cell numbers at the surface exceeded $10^{6} \mathrm{I}^{-1}$ (Table 1 ). However, at strongly mixed stations (Stns 5
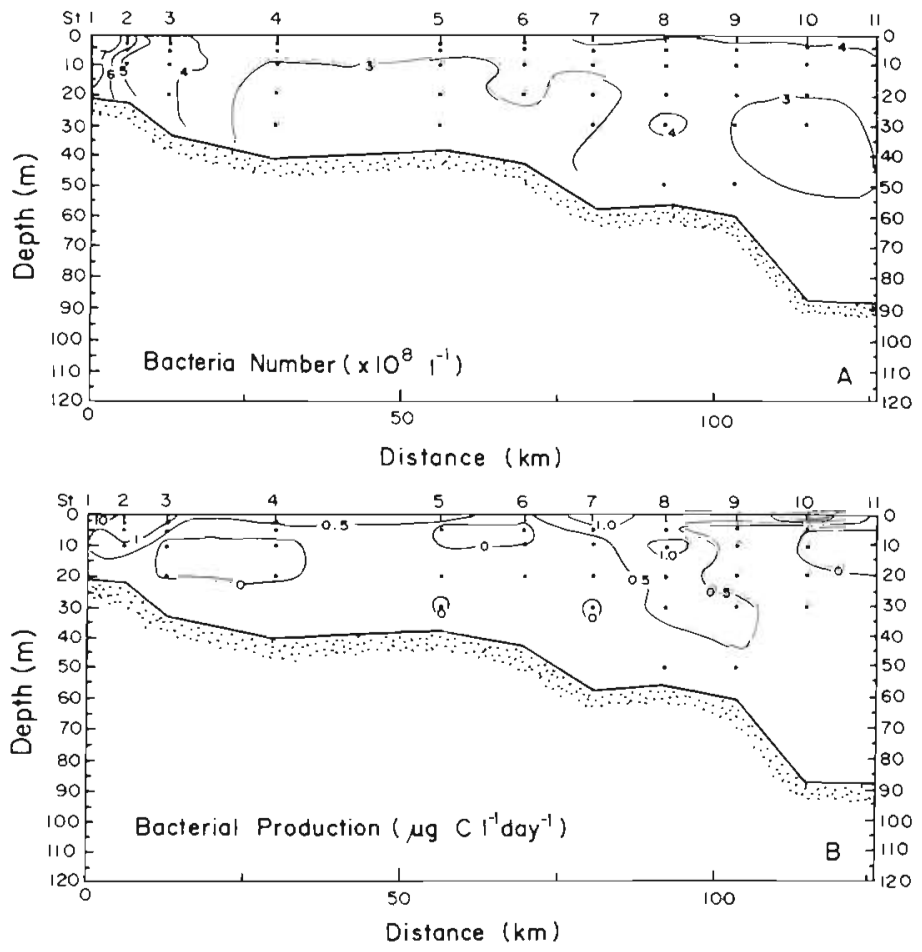

Fig. 5. Isopleth diagrams of (A) bacterial abundance and (B) production. (•) Depth at which sample was taken and 8) with high concentrations of SPM compared to the adjacent waters, phytoplankton cell numbers were markedly decreased $\left(10^{5} \mathrm{I}^{-1}\right)$. Chain-forming or large diatoms (Skeletonema costatum, Thalassiosira decipiens, Chaetoceros densus, and Paralia sulcata) were the dominant species along the transect (Table 1) except at Stns 6 and 7 where a mixed and a weakly stratified water column existed, respectively. At both Stns 6 and 7 , flagellates (Prorocentrum micans and $P$. triestinum) and nanophytoplankton (unidentified) were dominant ( $>83 \%$ ). In the study area, phytoplankton community structures were similar within the shallow euphotic zone (data not shown).

\section{Distribution of bacterial abundance and production}

Bacterial abundance of the coastal region was higher than that of offshore regions. The highest bacterial abundance $\left(31.9 \times 10^{8} \mathrm{I}^{-1}\right)$ occurred at the inner Stn 1 (Fig. 5A). Bacterial abundance at the surface decreased to $4.1 \times 10^{8} \mathrm{l}^{-1}$ at $\operatorname{Stn} 3$ 
Table 1 Dominant species of phytoplankton at the surface as percentage of total cell numbers

\begin{tabular}{|c|c|c|c|}
\hline Stn & Dominant species & Eell numbers $\left(\mathrm{I}^{-1}\right)$ & $\%$ \\
\hline \multirow[t]{3}{*}{2} & Skeletonema costatum & 1787411 & 62 \\
\hline & Thalassiosira decipiens & 182413 & 6 \\
\hline & Nanoplankton & 613571 & 21 \\
\hline \multirow[t]{3}{*}{3} & S. costatum & 988500 & 66 \\
\hline & $T$. decipiens & 123000 & 8 \\
\hline & Nanopjaakton & 243000 & 16 \\
\hline \multirow[t]{5}{*}{4} & S. costatum & 38669 & 19 \\
\hline & Chaetoceros densus & 30528 & 15 \\
\hline & Prorocentrum micans & 30528 & 15 \\
\hline & P. triestinum & 38669 & 19 \\
\hline & Nanoplankton & 40704 & 20 \\
\hline \multirow[t]{3}{*}{5} & Paralia sulcata & 23331 & 21 \\
\hline & Plagiogramma vanheureckij & 9999 & 9 \\
\hline & Nanoplankton & 49995 & 45 \\
\hline \multirow[t]{4}{*}{6} & S. costatum & 14140 & 7 \\
\hline & P. micans & 30300 & 14 \\
\hline & P. triestinum & 56560 & 26 \\
\hline & Nanoplankton & 92900 & 43 \\
\hline \multirow[t]{4}{*}{7} & P. micans & 14586 & 21 \\
\hline & P. triestiaun & 8976 & 13 \\
\hline & Nanoplankton & 34782 & 50 \\
\hline & Gonyauiax polygramma & 4488 & 6 \\
\hline \multirow[t]{4}{*}{8} & Grammatophora undulata & 7315 & 8 \\
\hline & S. costatum & 13585 & 14 \\
\hline & P. sulcata & 9405 & 10 \\
\hline & Nanoplankton & 47025 & 48 \\
\hline \multirow[t]{2}{*}{9} & S. costaium & 365742 & 73 \\
\hline & T. decipiens & 56392 & 11 \\
\hline \multirow[t]{2}{*}{10} & S. costatum & 2474712 & 79 \\
\hline & T. decipiens & 328320 & 10 \\
\hline \multirow[t]{5}{*}{11} & Nitzschia sigma & 8610 & 6 \\
\hline & P. micans & 15068 & 10 \\
\hline & S. costatum & 55965 & 38 \\
\hline & T. decipiens & 27983 & 19 \\
\hline & Nanoplankton & 23678 & 16 \\
\hline
\end{tabular}

(12.6 $\mathrm{km}$ offshore), and then varied within a narrow range $\left(3.2\right.$ to $\left.4.8 \times 10^{8} 1^{-1}\right)$ in the water column beyond Stn 3 .

Bacterial production ranged from undetectable to $11.9 \mu \mathrm{g} \mathrm{C}^{-1} \mathrm{~d}^{-1}$ and varied greatly in the water column along the transect (Fig. 5B). In general, a thin layer (ca $5 \mathrm{~m}$ ) of moderately low bacterial production (>0.5 $\mu \mathrm{g} \mathrm{C} \mathrm{l}^{-1} \mathrm{~d}^{-1}$ ) floated on the bottom layer of much lower bacterial production. The water bodies with undetectable bacterial production were interspersed at a 3 to $30 \mathrm{~m}$ depth interval along the transect. The isopleth of $0.5 \mu \mathrm{g} \mathrm{Cl}^{-1} \mathrm{~d}^{-1}$ deepened at the inner Stns 1 to 3 where relatively high bacterial production was found and at Stn 8 where mixing was suggested (Fig. 2C). At the stations with high SPM concentrations (Stns 5, 6, and 8) bacterial production in the euphotic zone was much lower than in the adjacent waters (Table 2). The gross features of distributions of bacterial abundance and production did not reflect that of hydrography.

Based on bacterial production and biomass data, bacterial doubling times in the euphotic zone were estimated to vary from $1.2 \mathrm{~d}$ to infinity with an average doubling time of $23.8 \pm 27.4 \mathrm{~d}$ ( $\mathrm{n}=26$, without including values of infinity). The fastest bacterial growth was found at the surface of inner Stns 1 and 2.

\section{Interrelationships between bacteria and phytoplankton}

Bacterial abundance did not significantly correlate with chl a $\left(\mathrm{r}^{2}=0.04, \mathrm{p}=0.28\right)$ or primary production $\left(\mathrm{r}^{2}=0.15, \mathrm{p}=0.27\right)$. Bacterial production did not significantly correlate with chl a $\left(r^{2}=0.09, p=0.12\right)$ or primary production $\left(\mathrm{r}^{2}=0.07, p=0.35\right)$, indicating weak response of bacteria to a spring bloom. Bacterial production did not significantly correlate with bacterial abundance $\left(r^{2}=0.01, p=0.57\right)$ in the euphotic zone. Depth-integrated bacterial abundance over the euphotic zone correlated significantly with the depth of the euphotic zone $\left(\mathrm{r}^{2}=0.77, \mathrm{p}=0.001\right)$, indicating a relatively homogeneous distribution of bacteria in the euphotic zone. Depth-integrated bacterial abundance

Table 2. Comparison of depth-integrated bacterial production over the euphotic depth $\left(\mathrm{BP}_{\mathrm{E}}\right)$ and whole water column (BPw) with depth-integrated primary production (PP) along a transect in the Yellow Sea from April 8 to 18, 1991. The surface turbidity maximum was found at $\mathrm{Stn} 5$. Production given in $\mathrm{mg} \mathrm{C} \mathrm{m} \mathrm{m}^{-2} \mathrm{~d}^{-1}$

\begin{tabular}{|lrrrrrrrrrr|}
\hline & \multicolumn{10}{c|}{ Station } \\
& 2 & 3 & 4 & 5 & 6 & 7 & 8 & 9 & 10 & 11 \\
\hline $\mathrm{PP}$ & 1048 & 913 & 140 & 92 & 144 & 500 & 84 & 499 & 3175 & 723 \\
$\mathrm{BP}$ & 28.2 & 3.3 & 2.7 & 1.4 & 0.7 & 7.6 & 2.8 & 4.2 & 4.5 & 2.3 \\
$\mathrm{BP}$ & 33.7 & 5.5 & 5.5 & 6.4 & 15.7 & 12.8 & 31.8 & 24.5 & 8.5 & 11.5 \\
$\mathrm{BP}$ & 2.6 & 0.3 & 1.9 & 1.5 & 0.4 & 1.5 & 3.3 & 0.8 & 0.1 & 0.3 \\
$\mathrm{BP}$ & 3.2 & 0.6 & 3.9 & 7.0 & 10.9 & 2.6 & 37.9 & 4.9 & 0.3 & 1.6 \\
\hline
\end{tabular}



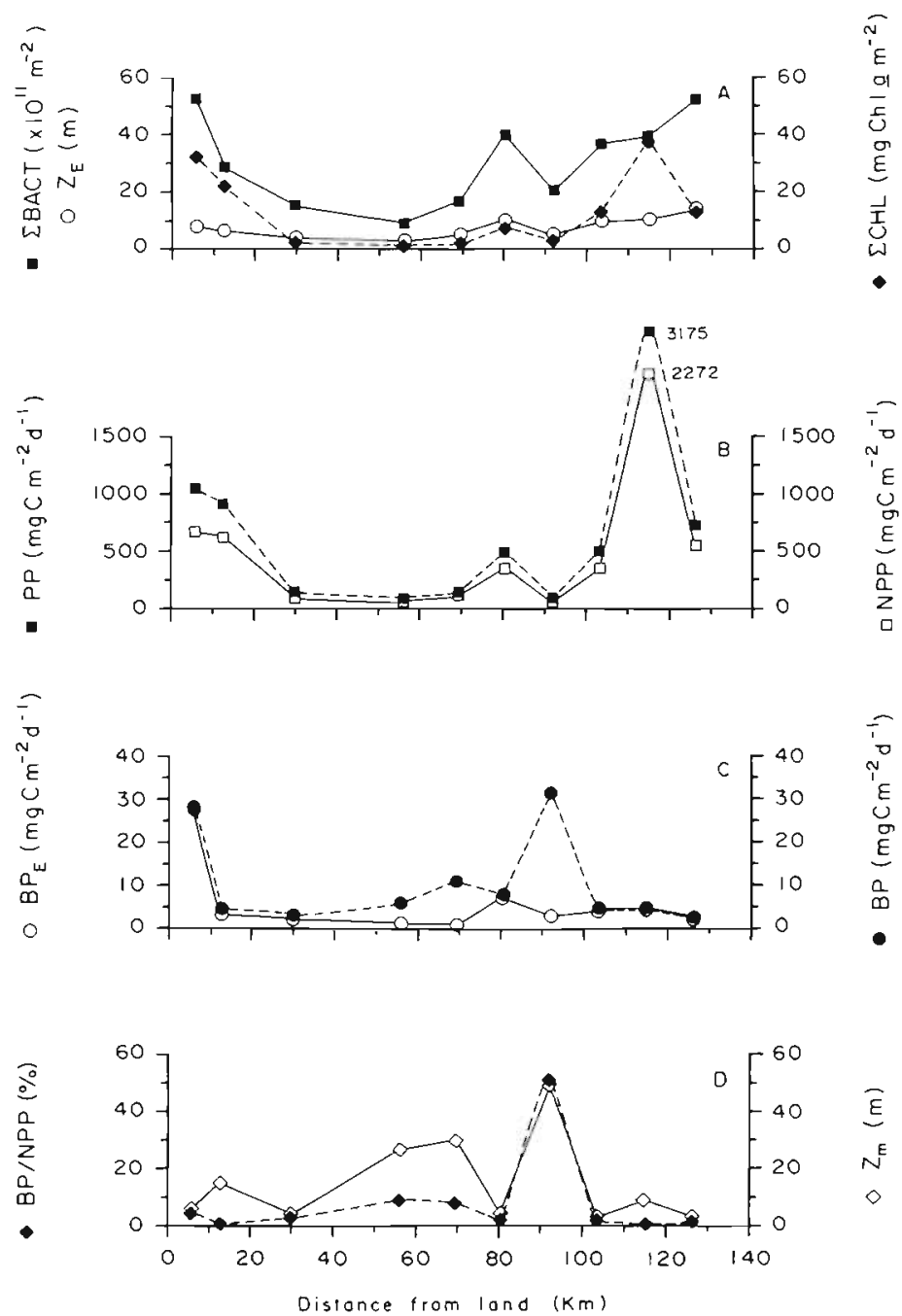

Fig. 6. Bacteria and phytoplankton in the Yellow Sea in April, 1991. (A) Depth-integrated bacterial abundance and chl a over the euphotic zone, and the euphotic depth $\left(Z_{E}\right)$. (B) Primary production (PP), and net phytoplankton production (NPP). (C) Bacterial production integrated over the euphotic zone $\left(B P_{E}\right)$ and bacterial production integrated (BP) over the depth of the mixed layer or the euphotic depth, whichever was deeper. The depth of the mixed layer $\left(Z_{m}\right)$ was defined as the depth where $\Delta \sigma_{t}$ from surface $\sigma_{t}$ was 0.25 . (D) Values of $\mathrm{BP} / \mathrm{NPP}$ and $Z_{\mathrm{m}}$ along the transect

over the euphotic zone correlated significantly with depth-integrated chl a over the euphotic zone $\left(\mathrm{r}^{2}=\right.$ $0.45, p=0.034$ ), but depth-integrated chl a over the euphotic zone did not correlate significantly with the depth of the euphotic zone $(p=0.18)$. Depth-integrated chl a over the euphotic zone correlated significantly with the euphotic depth only when data of inner and outer stations (Stns 2, 3, 10, and 11) with elevated primary production and chl a (Figs. $6 \mathrm{~A}, \mathrm{~B}$ ) were excluded. These results again indicate different distributions of bacteria and chl $a$ in the euphotic zone and different responses of bacteria and phytoplankton to changing depth of the euphotic zone during the study period. Depth-integrated bacterial production for the euphotic zone did not correlate with the depth-integrated primary production $\left(r^{2}=0.04\right.$, $\mathrm{p}=0.59$ ) and comprised a very small portion of it $(1.3 \pm 1.1 \%, n=10$, Table 2, Fig. 6). Depth-integrated bacterial production for the whole water column did not correlate with primary production $\left(r^{2}=0.02, p=0.68\right)$ and also comprised a small portion of it $(7.3 \pm 11.2 \%, \mathrm{n}=10$, Table 2$)$. Temperature correlated weakly, but significantly, with chl a $\left(\mathrm{r}^{2}=0.27, \mathrm{p}=0.01\right)$, bacterial abundance $\left(r^{2}=0.37, p=0.003\right)$, and bacterial production $\left(\mathrm{r}^{2}=0.23, \mathrm{p}=0.02\right)$. This seemed to be related to a weak stratification in Stn 2; when data from Stn 2 were excluded, temperature barely correlated only with bacterial abundance $\left(\mathrm{r}^{2}=0.21, \mathrm{p}=0.05\right)$.

\section{DISCUSSION}

A dominant physical characteristic of the study area was the strong activity of tidal mixing as indicated by the fact that the whole study area differed in temperatures by $<4{ }^{\circ} \mathrm{C}$ over $150 \mathrm{~km}$ distance and up to $110 \mathrm{~m}$ deep. Especially the top $30 \mathrm{~m}$ layer showed $<1^{\circ} \mathrm{C}$ temperature difference in most of the study area. As a consequence of the tidal mixing, surface waters were turbid and rich with nutrients. High nutrient concentrations in the euphotic zone (ammonium ranged from ca 0.1 to $0.5 \mu \mathrm{M}$; nitrate 2.0 to $10.7 \mu \mathrm{M}$; phosphate 0.7 to $1.9 \mu \mathrm{M}$; Hong 1991) were favorable to phytoplankton growth. Assimilation numbers of phytoplankton in the study area ranged from 6 to $20 \mathrm{mg} \mathrm{C} \mathrm{mg}^{-1} \mathrm{chl} \mathrm{a}$

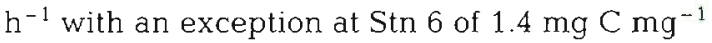
chl a $\mathrm{h}^{-1}$ (Hong 1991), indicating an active state of phytoplankton. The high phytoplankton cell numbers and chl $a$ indicated an ongoing spring phytoplankton bloom in coastal stations and offshore stations. The dominance of tidal action also caused high SPM concentrations in the water column (Fig. 3), which resulted in light-limiting conditions (Secchi depth usually $<4 \mathrm{~m}$ ) in surface waters. Thus, organic matter production was restricted within a thin layer $(<10 \mathrm{~m})$, which in turn restricted bacterial production in most stations to $<10 \mathrm{~m}$ depth (Fig. 5). Bacterial abundance and production during the study period were generally low (mostly in the ranges of 3 to $9 \times 10^{8} \mathrm{l}^{-1}, 0$ to $1 \mu \mathrm{g} \mathrm{Cl}^{-1} \mathrm{~d}^{-1}$ ) considering the observed values of chl $a$ and primary production (Fuhrman \& Azam 1982, Bird \& Kalff 1984, Cho \& Azam 1990). Interestingly, the ranges of bacterial and phytoplank- 
ton variables, water temperature, nutrient concentrations, and well-mixed conditions in our study area were similar to those found in the North Sea during a spring bloom (Nielsen \& Richardson 1989). Nielsen \& Richardson (1989) also found that a minor fraction of primary production flowed through the 'microbial loop' in the euphotic zone during a spring bloom as in our study. Below, we will discuss strong tidal mixing as a possible cause of the uncoupling of bacteria and phytoplankton in our study.

For the uncoupling of bacterial abundance and chlorophyll in the New York Bight, where freshwaters of the Hudson River outflow in the plume, Ducklow \& Kirchman (1983) explained it as being due to allochthonous inputs of dissolved organic matter on which bacteria grew. Within the warm-core ring, Ducklow (1984) found an uncoupling of bacterial abundance and chlorophyll due to different vertical distributions of bacteria and chlorophyll. In our study, however, allochthonous inputs of dissolved organic matter would not account for the insignificant correlation between bacterial abundance and chl a or primary production because bacterial production in the euphotic zone comprised only $<4 \%$ of primary production throughout the study region. Since tidal mixing is strong in our area, depth-integrated bacterial production over the whole water column was compared with primary production (Table 2). Again, bacterial production was a small portion (mean of $7.3 \%$ ) of primary production. Different spatial distributions of bacteria and chlorophyll (Figs. 4 \& 5) would in part explain the insignificant correlations during the study. Also, this may be partly due to low bacterial growth rates compared to healthy phytoplankton growth in this study.

Probably the first report on the uncoupling between bacterial and phytoplankton growth was from a northern polar marine environment, Newfoundland (Pomeroy \& Deibel 1986). Pomeroy \& Deibel (1986) found that very low seawater temperature was the cause of the uncoupling. At about $0^{\circ} \mathrm{C}$ seawater temperature, bacterial growth was inhibited but phytoplankton growth was not. Thus, the phytoplankton production and its sinking could support the high benthic and fish productions. Further, low substrate level is recognized to be another important factor for the uncoupling at such a low ambient temperature (Pomeroy et al. 1991). Off central Chile, McManus \& Peterson (1988) reported that bacteria at a nearshore station were uncoupled from phytoplankton in newly upwelled water. This was mainly due to advected allochthonous organic matter from offshore. The uncoupling found for the bacterial and primary production in our study was not apparently due to very low temperature or to inputs of allochthonous organic matter into the study area.
Another cause of the uncoupling has been reported: in the North Bering/Chukchi Seas at a relatively stable diatom dominated station, Andersen (1988) observed that only $5 \%$ of primary production entered the microbial loop. Here, sinking and benthic consumption of primary production and grazing let planktonic bacteria use only a small fraction of primary production. A similar observation was found in the North Sea during a spring bloom (Nielsen \& Richardson 1989), and sinking of the bulk of primary production was suggested as the cause. Possibly, in our study area much of primary production by large diatoms was not used by bacteria and lost to the bottom via sinking. High chl a concentrations below the euphotic zone, and sediment trap data suggest such a possibility. Sinking carbon flux at $30 \mathrm{~m}$ depth (far below the euphotic zone) at a trap station (96 $\mathrm{mg} \mathrm{C} \mathrm{m}^{-2} \mathrm{~d}^{-1}$ and $9.9 \mathrm{mg} \mathrm{N} \mathrm{m}^{-2} \mathrm{~d}^{-1}$; Hong 1991) represented $67 \%$ and $19 \%$ of primary production at the adjacent Stns 6 and 7 , respectively. Since our sediment trap was moored in a very high SPM environment, we may have collected a substantial portion of resuspended materials as indicated by an observation that organic carbon comprised only $0.97 \%$ of the sinking particulate matter (Hong 1991). This data itself might not be robust enough to conclude high sinking of primary production as an explanation of the observed uncoupling in our study. In addition, phytoplankton community structure was thought to be responsible for the uncoupled relationship between bacterial production and primary production (Andersen 1988). In most stations in our study region, large diatoms or chain-forming diatoms (Thalassiosira decipiens, Skeletonema costatum, Paralia sulcata, Chaetoceros densus) were the dominant phytoplankton taxa (Table 1). At Stns 6 and 7, flagellates and nanophytoplankton were the major taxa. Comparison of phytoplankton community structure with the ratios of depthintegrated bacterial production to primary production was interesting; the ratios for Stns 6 and 7 were not substantially different from the ratios for the other stations (Table 2). Thus, the variation in the ratios of depth-integrated bacterial production to primary production (i.e. variation in the uncoupling between bacterial production and primary production) in our study area might not be explained by community structure of phytoplankton along the transect. Further, since net production of organic matter begins in the middle of March near the study area (Chung \& Yang 1991) and time lag in bacterial response to a spring bloom is reported to be only 10 d (Lancelot \& Billen 1984), the time lag in bacterioplankton response to the spring bloom would not explain the observed uncoupling.

We propose a scenario to explain the observed uncoupling of bacterial and phytoplankton productions as follows: our study area is subject to strong tidal 
mixing, and thus is highly turbid and light-limited. This physical environmental condition would restrict organic matter production within the thin euphotic layer $(<10 \mathrm{~m})$, while the depth of the mixed layer is mostly similar to or much deeper than the euphotic zone (Fig. 6A, D). The strong tidal mixing is expected to have a few direct effects on bacterial utilization of organic matter and consequently on carbon flow through bacteria. As mixing deepens in the water column, phytoplankton production would be increasingly respired by the biological communities until the mixed depth approaches the critical depth. Since bacteria are recognized as a major agent of pelagic respiration (Williams 1984, Griffith et al. 1990), we expect that bacterial production would comprise a major fraction of net phytoplankton production in strongly mixed stations and a small fraction in weakly mixed stations. This is tested by correlating the ratios of depth-integrated bacterial production (BP) to net phytoplankton production (NPP) with mixed layer depth (Fig. 6D). Here, BP was defined as bacterial production integrated over the depth of the mixed layer or the euphotic depth, whichever was deeper. Mixed layer depth $\left(Z_{\mathrm{m}}\right)$ was defined as the depth where the difference from surface $\sigma_{\mathrm{t}}$ is equivalent to $\Delta \sigma_{\mathrm{t}}$ of 0.25 , which gave a better correlation than other values of $\Delta \sigma_{\mathrm{t}}$ (not shown). Net phytoplankton production was calculated by correcting for phytoplankton respiration conservatively by substracting $5 \%$ of maximum photosynthetic rate from gross phytoplankton production (Cole et al. 1992). As expected, the result shows a highly significant positive relationship $[\mathrm{BP} / \mathrm{NPP}(\%)=-4.83+$ $0.86 Z_{\mathrm{m}} ; \mathrm{r}^{2}=0.78, \mathrm{p}=0.001$, see Fig. $6 \mathrm{D}$ ]. This result indicates that in a strongly mixed water column most of phytoplankton production would be channeled to the microbial loop. This is consistent with the observation that net water column production is negative when photic depth is less than ca $20 \%$ of the mixed depth (Cloern 1987). Possibly, in the deep mixed layer (ca $100 \mathrm{~m}$ ) of the North Sea where direct transfer of the bulk of primary production to the aphotic zone was suggested (Nielsen \& Richardson 1989), the transported primary production might be substantially used up by bacteria.

Also, the values of $\mathrm{BP}_{\mathrm{W}} / \mathrm{PP}(\%)$, percentage ratios of depth-integrated bacterial production over the watercolumn to primary production, were high at stations with a deep mixed layer $(7.0$ to $37.9 \%$ at Stns 5,6 , and 8 ; Table 2). However, these stations showed similarly low values of $\mathrm{BP}_{\mathrm{E}} / \mathrm{PP}(\%)$ when compared to other stations (Table 2), suggesting that bacterial utilization of phytoplankton production below the euphotic zone was greatly enhanced in strongly mixed stations. For example, we can compare Stns 4 and 6 where primary production values were quite similar to each other
(Table 2), but the depth of the mixed layer was 3.9 and $30 \mathrm{~m}$, respectively. At Stn 4, where mixing was weak, $\mathrm{BP}_{\mathrm{W}} / \mathrm{PP}$ was only 2 -fold higher than $\mathrm{BP}_{\mathrm{E}} / \mathrm{PP}$, whereas enhanced (27-fold) bacterial utilization of primary production was found in the aphotic zone in the strongly mixed Stn 6. An intriguing question then is, why was enhanced bacterial utilization of primary production not found in the aphotic zone in weakly mixed stations? We believe that strong mixing somehow facilitated conversion of sinking phytoplankton production into dissolved organic matter in the aphotic zone. Thus, water-column bacterial utilization of primary production was enhanced in strongly mixed waters. In fact, $\mathrm{BP}_{\mathrm{W}} / \mathrm{PP}$ correlated positively and significantly with the depth of the mixed layer $\left(r^{2}=0.78, p=0.001\right)$. This mechanism might explain the wide variations (126-fold) in $\mathrm{BP}_{\mathrm{w}} / \mathrm{PP}$ during the study period.

Next, strong tidal mixing would force the bacteria to experience periodically changing environments and therefore unbalanced growth (Chin-Leo \& Kirchman 1990). Bacteria with slow growth rates (mostly with doubling times $>5 \mathrm{~d}$ ), living in continually mixed environments, would not adapt effectively to shift-up conditions afforded by photosynthesis. This seems to be consistent with the result that bacterial abundance insignificantly correlated ( $p=0.57$ ) with bacterial production. However, the reasons for slow bacterial growth rates during the study period are not clear. Such slow growth rates of bacteria (doubling times of $24 \pm 27 \mathrm{~d}, \mathrm{n}=26$ ) are not found in the other coastal region of the Yellow Sea in April (Cho \& Shim 1992); the bacterial doubling times ranged from 2 to $21 \mathrm{~d}$ ( $7 \pm$ $5 \mathrm{~d}, \mathrm{n}=22$ ) in the euphotic zone. Also, in the mideast part of the Yellow Sea bacterial doubling time is reported to be $0.6 \pm 0.3 \mathrm{~d}(\mathrm{n}=6)$ in the euphotic zone in April (Son 1989). Our slow growth rates might be due partly to physical mixing which dilutes the newly photosynthesized organic matter into the deep mixed layer causing low substrate levels for bacteria in the euphotic zone. Possibly, major loss of phytoplankton production to the aphotic zone would occur, as $\mathrm{BP} / \mathrm{PP}$ data in strongly mixed waters and sediment trap data suggested. All these possibilities combined with unbalanced growth would cause the observed uncoupling of bacteria from phytoplankton in the euphotic zone. Further, the uncoupling of bacterial and phytoplankton productions would be exaggerated if the carbon assimilation efficiency of bacteria was low during the study.

Our conclusion on the uncoupling between bacterial production and primary production would be biased if attached bacteria were dominant and their biovolumes were large. Except for samples near the bottom, attached bacteria were a small fraction of total bacteria $(<15 \%$; S. S. Yoon pers. comm.). Although we did not 
measure biovolumes of the attached bacteria, they did not seem to be much larger than free-living bacteria under microscopic examinations. This is consistent with recent findings that free-living bacteria were dominant even in turbid estuarine samples (Kirchman et al. 1989, Griffith et al. 1990). The other factor to be considered is a conversion factor for thymidine incorporation in attached bacteria. Iriberri et al. (1990) reported that conversion factors for the attached and free-living bacteria were similar. Thus, even if large biovolume (e.g. $0.2 \mu^{3}$ ) and a higher conversion factor of biovolume to carbon $\left(0.175 \mathrm{~g} \mathrm{C} \mathrm{ml}^{-1}\right.$; Simon \& Azam 1989) are employed to account for the attached bacteria in our samples, our conclusion of the uncoupled bacterial production from primary production will not be affected. Finally, the use of $10 \mathrm{nM}$ thymidine as employed here has been assumed to saturate uptake of thymidine (Fuhrman \& Azam 1982). Logan \& Fleury (1993) recently suggested that thymidine incorporation was non-saturable even at $\mathrm{mM}$ concentrations. It thus remains to be confirmed whether the use of 10 to $20 \mathrm{nM}$ thymidine with a current conversion factor is appropriate to quantitatively measure bacterial production.

In conclusion, strong tidal mixing might cause uncoupling between bacteria and phytoplankton during a spring bloom. Further studies on respiration activity in bacteria and growth status are needed to elucidate how such physiological conditions could influence the carbon flux through bacteria in continuously mixed environments

Acknowledgements. We thank Dr M. Simon for stimulating comments on the early version of this manuscript, and Dr F. Azam and 2 anonymous reviewers for their helpful comments on the manuscript. We thank Mr S. H. Kim and Mr S. Kang for their assistance in field work and the captain and crews of RV 'Banwol' for cooperative work during the study. This study was supported by grants 1991 and 1992 (B.C.C., J.K.C.) from KOSEF and by a grant from the Korean Ministry of Science and Technology (G.H.H.).

\section{LITERATURE CITED}

Abe, T H. (1967). The armoured dinoflagellate. II. Prorocentridae Dinophysidae. (b) Dinophysis and its allied genera. Publ. Ste. Mar. Biol. Lab. 15: 37-58

Andersen, P. (1988). The quantitative importance of the 'microbial loop' in the marine pelagic: a case study from the North Bering/Chukchi seas. Ergebn. Limnol. 31. $243-251$

Azam, F., Fenchel, T., Field, J. G., Gray, J. S., Meyer-Reil, L.-A., Thingstad, F. (1983). The ecological role of watercolumn microbes in the sea. Mar. Ecol. Prog. Ser. 10: $257-263$

Azam, F., Smith, D. C. (1991). Bacterial influence on the variability in the ocean's biogeochemical state: a mechanistic view. In: Demers, S. (ed.) Particle analysis in oceanogra- phy. NATO ASI Series, Vol. G 27. Springer-Verlag, Berlin, p. 213-236

Billen, G., Servais, P., Becquevort, S. (1990). Dynamics of bacterioplankton in oligotrophic and eutrophic aquatic environments: bottom-up or top-down control? Hydrobiologia 207: 37-42

Burd, D. F., Kalff, J. (1984). Empirical relationships between bacterial abundance and chlorophyll concentration in fresh and marine waters. Can. J. Fish. Aquat. Sci. 41: $1015-1023$

Chin-Leo, G., Kirchman, D. L. (1990). Unbalanced growth in natural assemblages of marine bacteria. Mar. Ecol. Prog. Ser. 63: 1-8

Cho, B. C., Azam, F. (1990). Biogeochemical significance of bacterial biomass in the ocean's euphotic zone. Mar. Ecol. Prog. Ser. 63: 253-259

Cho, B. C., Shim, J. H. (1992). Significance of estuarine mixing in distribution of bacterial abundance and production in the estuarine system of the Mankyung River and Dongjin River, Korea. J. Oceanol. Soc. Kor. 27: 154-163

Chung, C.-S., Yang, D.-B. (1991). On the primary productivity in the southern sea of Korea. J. Oceanol. Soc. Kor. 26: $242-254$

Cloern, J. E. (1987). Turbidity as a control on phytoplankton biomass and productivity in estuaries. Cont. Shelf Res. 7 : $1367-1381$

Cole, J. J., Caraco, N. F., Peierls, B. L. (1992). Can phytoplankton maintain a positive carbon balance in a turbid, freshwater, tidal estuary? Limnol. Oceanogr. 37: $1608-1617$

Cole, J. J., Findlay, S., Pace, M. L. (1988). Bacterial production in fresh and saltwater ecosystems: a cross-system overview. Mar. Ecol. Prog. Ser. 43: 1-10

Cupp, E. E. (1943). Marine plankton diatoms of the west coast of North America. Bull. Scripps lnst. Oceanogr. 5: 1-237

Ducklow, H. W. (1984). Geographical ecology of marine bacteria: physical and biological variability at the mesoscale. In: Klug, M. J., Reddy, C. A. (eds.) Current perspectives in microbial ecology. American Society for Microbiology, Washington, DC, p. 22-31

Ducklow, H. W. Carlson, C. A. (1992). Oceanic bacterial production. In: Marshall, K. C. (ed.) Advances in microbial ecology, Vol. 12. Plenum Press, New York, p. 113-181

Ducklow, H. W., Kirchman, D. L. (1983). Bacterial dynamics and distribution during a spring bloom in the Hudson River plume, USA. J. Plankton Res. 5: 333-355

Fuhrman, J. A., Azam, F. (1982). Thymidine incorporation as a measure of heterotrophic bacterioplankton production in marine surface waters: evaluation and field results. Mar. Biol. 66: 109-120

Griffith, P. C., Douglas, D. J., Wainright, S. C. (1990). Metabolic activity of size-fractionated microbial plankton in estuarine, nearshore, and continental shelf waters of Georgia. Mar. Ecol. Prog. Ser. 59: 263-270

Hobbie, J. E., Daley, R. J., Jasper, S. (1977). A method for counting bacteria on Nuclepore filters. Appl, environ. Microbiol. 33: 1225-1228

Holligan, P. M., Harris, R. P., Newell, R. C., Harbour, D. S., Head, R. N. E., Linley, A. S., Lucas, M. I., Tranter, P. R. G., Weekley, C. M. (1984). Vertical distribution and partitioning of organic carbon in mixed, frontal and stratified waters of the English Channel. Mar. Ecol. Prog. Ser. 14: $111-127$

Hong, G. H. (1991). Coastal Ocean Flux Study in the mouth of the Yellow Sea. Technical Report. Korea Ocean Research \& Development Institute BSPG00132-391-4, Ansan (in Korean) 
Hüstedt, F. (1927-1966). Die Kieselalgen Deutschlands, Österreichs und der Schweiz mit Berücksichtigung der übrigen Länder Europas sowie der angrenzenden Meeresgebiete. In: L. Rabenhorst Kryptogamenflora. Akademische Verlagsgesellschaft, Leipzig: Teil 1, p. 920 (1927-1930); Teil 2, p. $845(1931-1959) ;$ Teil 3, p. 816 (1961-1966)

Iriberri, J., Undurraga, A., Muela, A., Egea, L. (1990). Bacterial production and growth rate estimation from ${ }^{3} \mathrm{H}$ thymidine incorporation for attached and free-living bacteria in aquatic systems. Appl. environ. Microbiol. 56: $483-487$

Kiørboe, T., Kaas, H., Kruse, B., Møhlenberg, F., Tiselius, P., Ertebjerg, G. (1990). The structure of the pelagic food web in relation to water column structure in the Skagerrak. Mar. Ecol. Prog. Ser. 59: 19-32

Kirchman, D. L., Soto, Y., Wambeck, F. V., Bianki, M. (1989). Bacterial production in the Rhone river plume: effect of mixing on relationships among microbial assemblages. Mar. Ecol. Prog. Ser. 53: 267-275

Lancelot, C., Billen, G. (1984). Activity of heterotrophic bacteria and its coupling to primary production during the spring phytoplankton bloom in the southern bight of the North Sea. Limnol. Oceanogr. 29: 721-730

Lee, S.-H., Fuhrman, J. A. (1987). Relationships between biovolume and biomass of naturally derived marine bacterioplankton. Appl. environ. Microbiol. 53: 1298-1303

Legendre, L., Fevre, J. Le (1989). Hydrodynamical singularities as controls of recycled versus export production in oceans. In: Bergers, W. H. et al. (eds.) Productivity of the ocean: present and past. John Wiley \& Sons, New York, p. $49-63$

Logan, B. E., Fleury, R. C. (1993). Multiphasic kinetics can be an artifact of the assumption of saturable kinetics for microorganisms. Mar. Ecol. Prog. Ser. 102: 115-124

McManus, G. B., Peterson, W. T. (1988). Bacterioplankton production in the nearshore zone during upwelling off central Chile. Mar. Ecol. Prog. Ser. 43: 11-17

This article was presented by F. Azam, La Jolla, California, USA
Nielsen, T. G., Richardson, K. (1989). Food chain structure of the North Sea plankton communities: seasonal variations of the role of the microbial loop. Mar. Ecol. Prog. Ser. 56: $75-87$

Parsons, T. R., Maita, Y., Lalli, C. M. (1984). A manual of chemical and biological methods for seawater analysis. Pergamon Press, New York

Pomeroy, L. R., Deibel, D. (1986). Temperature regulation of bacterial activity during spring bloom in Newfoundland coastal waters. Science 233: 359-361

Pomeroy, L. R., Wiebe, W. J., Deibel, D., Thompson, R. J., Rowe, G. T., Pakulski, D. (1991). Bacterial responses to temperature and substrate concentration during the Newfoundland spring bloom. Mar. Ecol. Prog. Ser. 75: 143-159

Rjemann, B., Bjørnsen, P. K., Newell, S., Fallon, R. (1987). Calculation of cell production of coastal marine bacteria based on measured incorporation of $\left[{ }^{3} \mathrm{H}\right]$ thymidine. Limnol. Oceanogr. 32: 471-476

Robarts, R. D., Wicks, R. J., Sephton, L. M. (1986). Spatial and temporal variations in bacterial macromolecule labelling with [methyl $\left.{ }^{3} \mathrm{H}\right]$ thymidine in a hypertrophic lake. Appl. environ. Microbiol. 52: 1368-1373

Sherr, E., Sherr, B. (1988). Role of microbes in pelagic food webs: a revised concept. Limnol. Oceanogr. 33: 1225-1227

Shim, J. H., Sin, Y. K., Cho, B. C. (1993). The roles and the interrelationships between bacteria and phytoplankton in the estuarine system of Mankyung and Dongjin rivers, Korea. J. Oceanol. Soc. Kor. 28: 107-113 (in Korean)

Simon, M., Azam, F. (1989). Protein content and protein synthesis rates of planktonic marine bacteria. Mar. Ecol. Prog Ser. 51: 201-213

Son, S. K. (1989). Studies on distribution of nutrients, heterotrophic activity and bacterioplankton production in the Yellow Sea. M.Sc. thesis, Inha University, Inchon

Williams, P. J. L. (1984). A review of measurements of respiration rates of marine plankton populations. In: Hobbie, J. E., Williams, P. J. L. (eds.) Heterotrophic activity in the sea. Plenum Press, New York, p. 357-389

Manuscript first received: January 24, 1994

Revised version accepted: August 29, 1994 